\title{
Effects of bovine $S M O$ gene polymorphisms on the body measurement and meat quality traits of Qinchuan cattle
}

\author{
Y.R. Zhang ${ }^{1}$, Y.K. Li ${ }^{1}$, C.Z. Fu ${ }^{1}$, J.L. Wang ${ }^{1}$, H.B. Wang ${ }^{1,2}$ and L.S. Zan ${ }^{1,2}$ \\ ${ }^{1}$ College of Animal Science and Technology, Northwest A\&F University, \\ Yangling, Shaanxi, China \\ ${ }^{2}$ National Beef Cattle Improvement Center of Northwest A\&F University, \\ Yangling, Shaanxi, China \\ Corresponding author: L.S. Zan \\ E-mail: zanlinsen@163.com
}

Genet. Mol. Res. 13 (4): 8105-8117 (2014)

Received July 26, 2013

Accepted November 29, 2013

Published October 7, 2014

DOI http://dx.doi.org/10.4238/2014.October.7.5

\begin{abstract}
Beef cattle breeding programs focus on improving important economic traits, including growth rates, and meat quantity and quality. Molecular marker-assisted selection based on genetic variation represents a potential method for breeding genetically improved livestock with better economic traits. Smoothened (SMO) protein is a signal transducer that contributes to the regulation of both osteogenesis and adipogenesis through the hedgehog pathway. In this study, we detected polymorphisms in the bovine $S M O$ gene of Qinchuan cattle, and we analyzed their associations with body measurement traits (BMTs) and meat quality traits (MQTs). Using DNA sequencing and polymerase chain reaction-restriction fragment length polymorphism, 3 novel single nucleotide polymorphisms were identified in the $S M O$ gene of 562 cattle: $1 \mathrm{G}>\mathrm{C}$ mutation on exon $9(\mathrm{G} 21234 \mathrm{C})$ and $2 \mathrm{C}>$ $\mathrm{T}$ mutations on exon 11 (C22424T and C22481T). Association analysis showed that polymorphisms on both the G21234C and C22424T loci significantly affected certain BMTs and MQTs $(\mathrm{P}<0.05$ or $\mathrm{P}<0.01)$,
\end{abstract}


whereas those on the $\mathrm{C} 22481 \mathrm{~T}$ locus did not $(\mathrm{P}>0.05)$. Therefore, the $S M O$ gene could be used as a candidate gene to alter BMTs and MQTs in Qinchuan cattle or for marker-assisted selection to breed cattle with superior BMTs and MQTs.

Key words: Body measurement traits; Meat quality traits; Qinchuan cattle; Smoothened; Polymorphisms

\section{INTRODUCTION}

Breeding programs of beef cattle focus on improving important economic traits, such as animal growth rates, and meat quantity and quality, to meet consumer demand and increase economic benefits. In general, body measurement traits (BMTs) and meat quality traits (MQTs) are used to assess the economic and breeding value of beef cattle. Economic traits tend to be influenced by the growth and development of various bovine tissues and organs, such as skeleton, adipose tissue, and musculature. The formation and growth of these tissues derive from stem cell differentiation through changing gene expression patterns that are regulated by transcription factors, signal pathways, and microRNAs.

The hedgehog $(\mathrm{Hh})$ signaling pathway plays a pivotal and conserved role in the embryonic development of both invertebrates and vertebrates (Ingham and McMahon, 2001; Jia and Jiang, 2006). McMahon et al. (2003) reported that the Hh pathway regulates the commitment of precursors into a diverse array of cell fates. Recent studies have indicated that the Hh pathway controls the specification of many mesodermal fates. For instance, it promotes myogenesis, osteogenesis, and hematopoiesis, but also inhibits adipogenesis (Li et al., 2004; Wu et al., 2004; Gering and Patient, 2005; Suh et al., 2006). In brief, the hedgehog pathway is essential for the patterning, growth, and morphogenesis of various animal tissues and organs (Ingham and McMahon, 2001; Varjosalo and Taipale, 2008).

The seven-pass transmembrane signal transducer of the Hh pathway is smoothened (SMO), which is a member of the G-protein-coupled receptor superfamily, and is encoded by the SMO gene (Alcedo et al., 1996; Ayers and Therond, 2010). The SMO receptor is in charge of changing the extracellular Hh protein signal into an intracellular Glil protein signal, resulting in the transcription of intranuclear genes (McMahon et al., 2003; Evangelista et al., 2006). SMO participates in or affects the regulation of either osteogenesis or adipogenesis through Hh pathway. Studies on cartilage development found that conditional removal of the $S M O$ gene could reduce chondrocyte proliferation, while the overexpression of a constitutively active $S M O$ allele could promote chondrocyte proliferation. Moreover, compared with wild-type littermates, mice generated by the knockout of the SMO gene might develop shorter long bones (Long et al., 2001). Recent studies on fat formation found that SMO is expressed in both mice and fly adipose tissue and that the expression of SMO decreases during the adipogenesis of 3T3-L1 cells. When SMO is continuously activated, 3T3-L1 cell differentiation is inhibited. In contrast, in the presence of KAAD, which is a specific and selective inhibitor of SMO, the adipogenesis of 3T3-L1 cells is stimulated (Suh et al., 2006). These results provide direct evidence that the $S M O$ gene contributes towards regulating both skeletal morphogenesis and adipogenesis.

To date, there has been no research on polymorphisms of the bovine SMO gene. On the basis of its role in bone morphogenesis and adipogenesis, as studied in Drosophila me- 
lanogaster and mice, we selected the $S M O$ gene as an attractive candidate gene for the improvement of BMTs and MQTs genetic in cattle. Therefore, in this study, we aimed to detect polymorphisms in the $S M O$ gene of Qinchuan cattle and investigate their associations with BMTs and MQTs. The results obtained about the SMO gene in this study are anticipated to provide useful information for further research to enhance the economic traits of beef cattle.

\section{MATERIAL AND METHODS}

\section{Genomic DNA sample isolation and data collection}

A total of 562 healthy Qinchuan cattle, aged from 18 to 24 months, were randomly selected from a Qinchuan cattle breeding population. Genomic DNA samples were extracted from blood collected from the jugular vein of all 562 cattle, according to a standard phenolchloroform extraction protocol (Mullenbach et al., 1989). According to previous descriptions (Gilbert et al., 1993), body measurement traits (BMTs), including body length (BL), wither height (WH), hip height (HH), rump length (RL), hip width (HW), chest depth (CD), heart girth (HG), and pin bone width (PBW), were measured by the same person to minimize systematic error. Ultrasound measurements, including measurements of backfat thickness (UBT) and loin muscle area (ULA), were collected for meat quality traits (Brethour, 1994; Hamlin et al., 1995) by a different person.

\section{PCR amplification and sequencing}

Based on the bovine SMO gene (GenBank accession No. NM_001192220.1), primer 1 (F: 5'-GCTTCACCCGTCTACTACCC-3', R: 5'-GCTCATGGAAATGCCAGTTC-3') and primer 2 (F: 5'-CCTTCAAACTGGGGATGGGT-3', R: 5'-ATCCATACCTGGCGTTGC-3') were designed by the Primer Premier 5.0 software to amplify a DNA fragment of $163 \mathrm{bp}$ from exon 9 and a DNA fragment of 319 bp from exon 11. For the 2 pairs of primers, PCR amplification was performed in a $20 \mu \mathrm{L}$ reaction mixture containing $50 \mathrm{ng}$ genomic DNA, $10 \mathrm{pM}$ of each primer, $0.20 \mathrm{mM}$ dNTPs, $2.5 \mathrm{mM} \mathrm{MgCl}_{2}$, and $0.5 \mathrm{U}$ Taq DNA polymerase (TaKaRa, Dalian, China). The cycling protocol was as follows: $95^{\circ} \mathrm{C}$ for $5 \mathrm{~min}, 35$ cycles of denaturing at $94^{\circ} \mathrm{C}$ for $30 \mathrm{~s}, 60.7^{\circ} \mathrm{C}$ annealing for $30 \mathrm{~s}$, and a final extension at $72^{\circ} \mathrm{C}$ for $30 \mathrm{~s}$, followed by a final extension at $72^{\circ} \mathrm{C}$ for $10 \mathrm{~min}$. PCR products were detected by electrophoresis on $1.5 \%$ agarose gel and purified by Axygen kits (MBI Fermentas, USA), and then sequenced in both directions in an ABI377 DNA analyzer (Applied Biosystems, USA). The sequence maps were analyzed by the SeqMan software. One G $>$ C mutation (G21234C) in exon 9 and another $2 \mathrm{C}$ $>$ T mutations (C22424T and C22481T) in exon 11 were detected in this study.

\section{Genotyping of the $S M O$ allele by PCR-RFLP}

The $S M O$ gene sequence was screened by the Primer Premier 5.0 software to identify the restriction sites for the 3 mutations identified in this study.

Aliquots of $10 \mu \mathrm{L} \mathrm{PCR}$ products were incubated with $10 \mathrm{U}$ restriction enzyme at $37^{\circ} \mathrm{C}$ for $16 \mathrm{~h}$, following the manufacturer protocol. The PCR products from Primer 1 were digested with Cfr13I (Takara, Dalian, China), and the PCR products from Primer 2 were separately 
digested with Cac8I (NEB, USA) and XceI (MBI Fermentas). The digested products were detected by electrophoresis on $2.0 \%$ agarose gel stained with ethidium bromide. The PCR products corresponding to different electrophoresis patterns were sequenced to validate the PCR-RFLP results.

\section{Statistical analyses}

According to previous methods provided by Nei and Roychoudhury (1974) and Nei and $\mathrm{Li}$ (1979), genotypes and allele frequencies, Hardy-Weinberg equilibrium, gene homozygosity $\left(H_{\mathrm{O}}\right)$, gene heterozygosity $\left(H_{\mathrm{E}}\right)$, effective allelic numbers $\left(N_{\mathrm{E}}\right)$, and polymorphism information content (PIC) were calculated. The SPSS software (version 17.0) was used to analyze the association between the SNP marker genotypes of the SMO gene and BMTs (BL, WH, HH, RL, HW, CD, HG, and PBW) and MQTs (UBT and ULA). The general linear model used in this study was:

$$
X_{i j k}=\mu+\alpha_{i}+\varepsilon_{j}+\delta_{i j k}
$$

(Equation 1)

where $X_{i j k}$ is the observation for each trait, $\mu$ is the overall mean for each trait, $\alpha_{i}$ is the genotype effect, $\varepsilon_{j}$ is the fixed effect of age, and $\delta_{i j k}$ is the random error.

\section{RESULTS}

\section{Genetic polymorphism of the Qinchuan cattle $S M O$ gene and $\chi^{2}$ test}

We amplified 163-bp and 319-bp DNA fragments from exons 9 and 11, respectively, of the $S M O$ gene in Qinchuan cattle. Analysis of sequencing maps using the SeqMan software revealed 3 novel SNPs: $1 \mathrm{G}>\mathrm{C}$ synonymous mutation of arginine in exon 9, corresponding to $\mathrm{G} 21234 \mathrm{C}$, and $2 \mathrm{C}>\mathrm{T}$ synonymous mutations of glycine and histidine in exon 11, corresponding to C22424T and C22481T. Both G21234C and C22424T SNPs had 3 genotypes each, namely, GG, GC, and CC (Figure 1A-C) and CC, CT, and TT (Figure 2A-C), respectively. In contrast, C22481T SNP had 2 genotypes, CC and CT (Figure 3A and B). Analysis of restriction sites using the Primer Premier 5.0 software showed that the 3 mutations (G21234C, $\mathrm{C} 22424 \mathrm{~T}$, and $\mathrm{C} 22481 \mathrm{~T})$ are located in the recognition sites of $C f r 13 \mathrm{I}\left(\mathrm{G}^{\wedge} \mathrm{GNCC}\right)$, Cac8I $\left(\mathrm{GCN}^{\wedge} \mathrm{NGC}\right)$, and $\mathrm{XceI}\left(\mathrm{RCATG}^{\wedge} \mathrm{Y}\right)$ restriction enzymes, respectively. When incubated with Cfr13I, the 163-bp PCR products produced 3 types of banding pattern for the G21234C SNP: specifically, 1 fragment (163 bp) for CC, 2 fragments (64 and $99 \mathrm{bp}$ ) for GG, and 3 fragments $(163,99$, and $64 \mathrm{bp}$ ) for GC (Figure 4). Moreover, when incubated with Cac8I, the 319-bp PCR products produced 3 types of banding patterns for the C22424T SNP: 1 fragment (319 bp) for TT, 2 fragments (178 and $141 \mathrm{bp}$ ) for CC, and 3 fragments $(319,178$, and $141 \mathrm{bp})$ for CT (Figure 5). In comparison, when digested by XceI, the same 319-bp PCR products produced 2 types of banding patterns for C22481T SNP: 1 fragment (319 bp) for CC and 3 fragments $(319,236$, and $83 \mathrm{bp})$ for CT (Figure 6). 
Effect of SNPs in the bovine SMO gene on economic traits
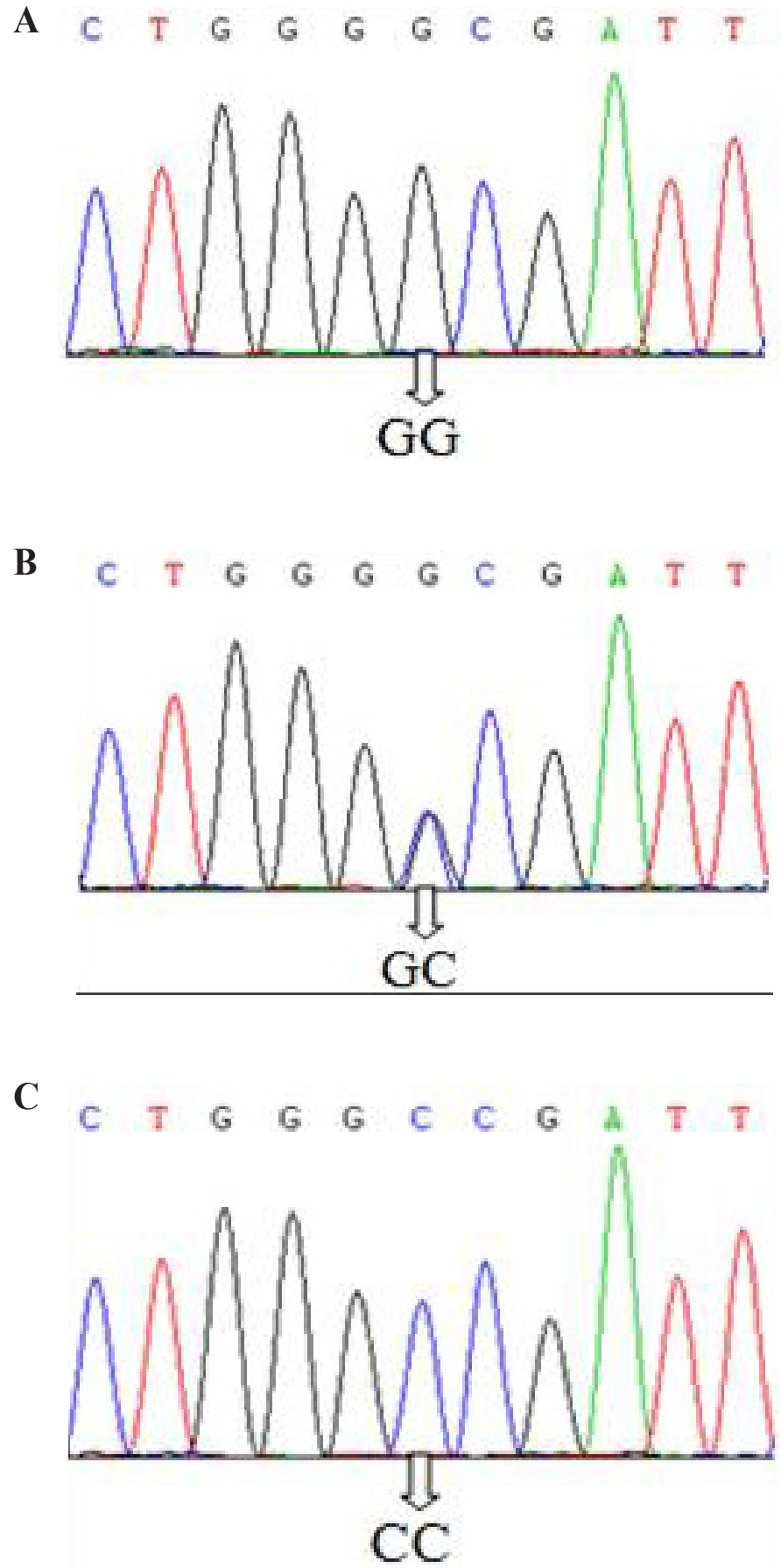

Figure 1. A. B. C. Sequencing map of G21234C mutation in bovine $S M O$ gene exon 9. 


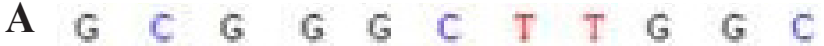

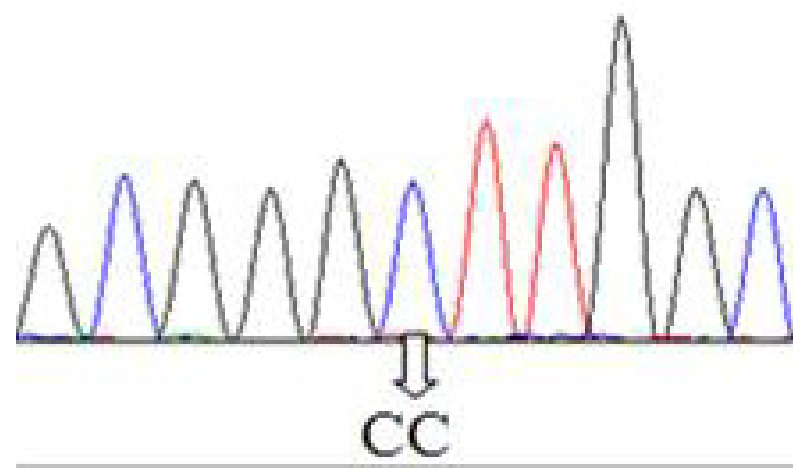

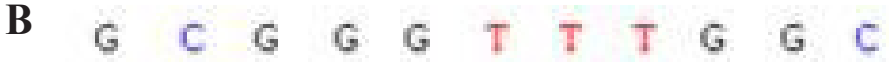

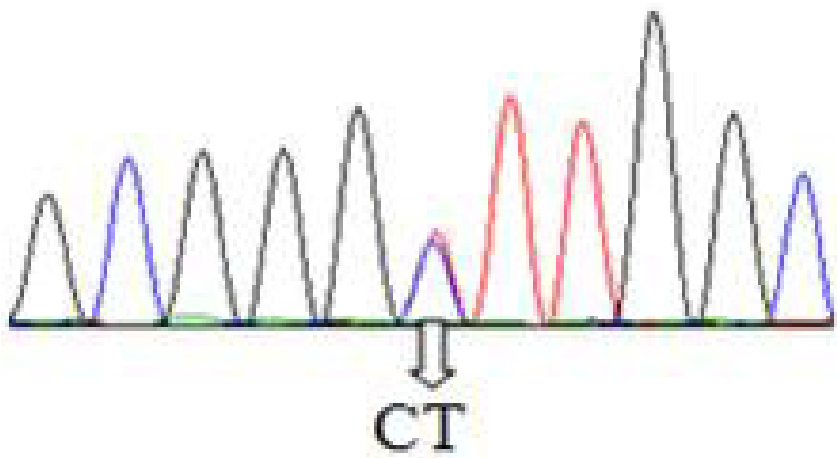

C $G \quad G \quad C \quad G \quad G \quad G \quad T \quad T \quad T \quad G \quad G \quad C$

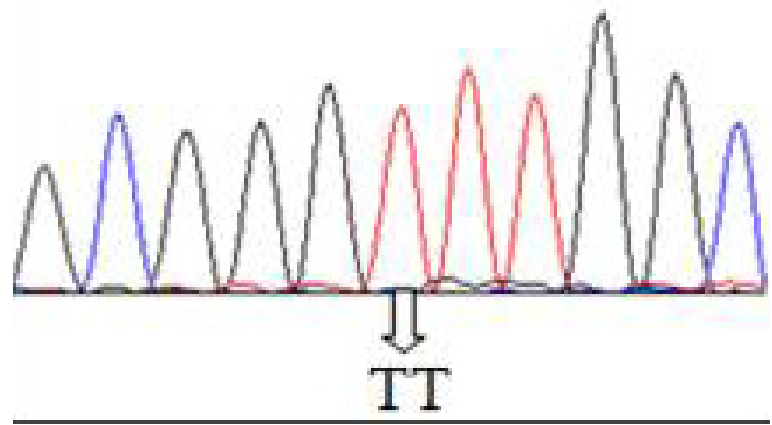

Figure 2. A. B. C. Sequencing map of C22424T mutation in bovine $S M O$ gene exon 11. 


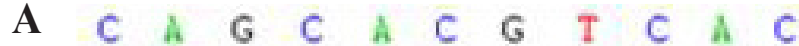

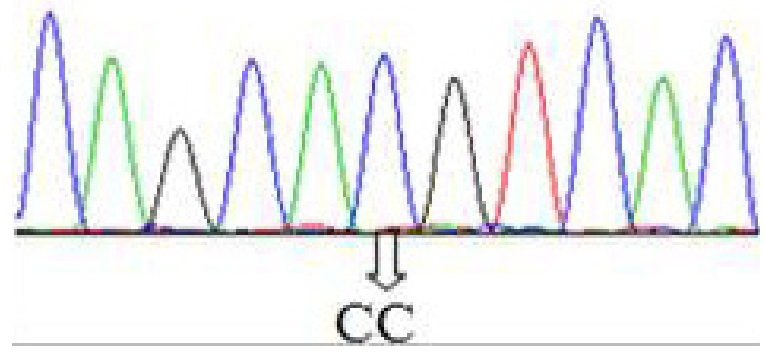

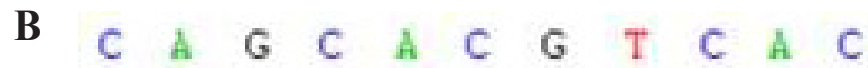

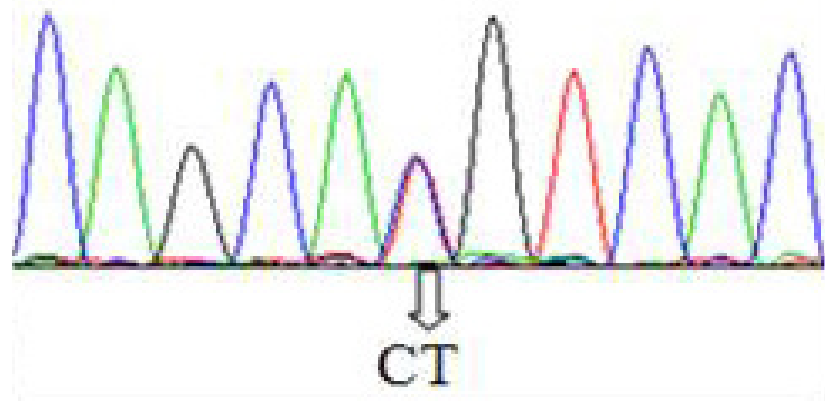

Figure 3. A. and B. Sequencing map of C22481T mutation in bovine $S M O$ gene exon 11.

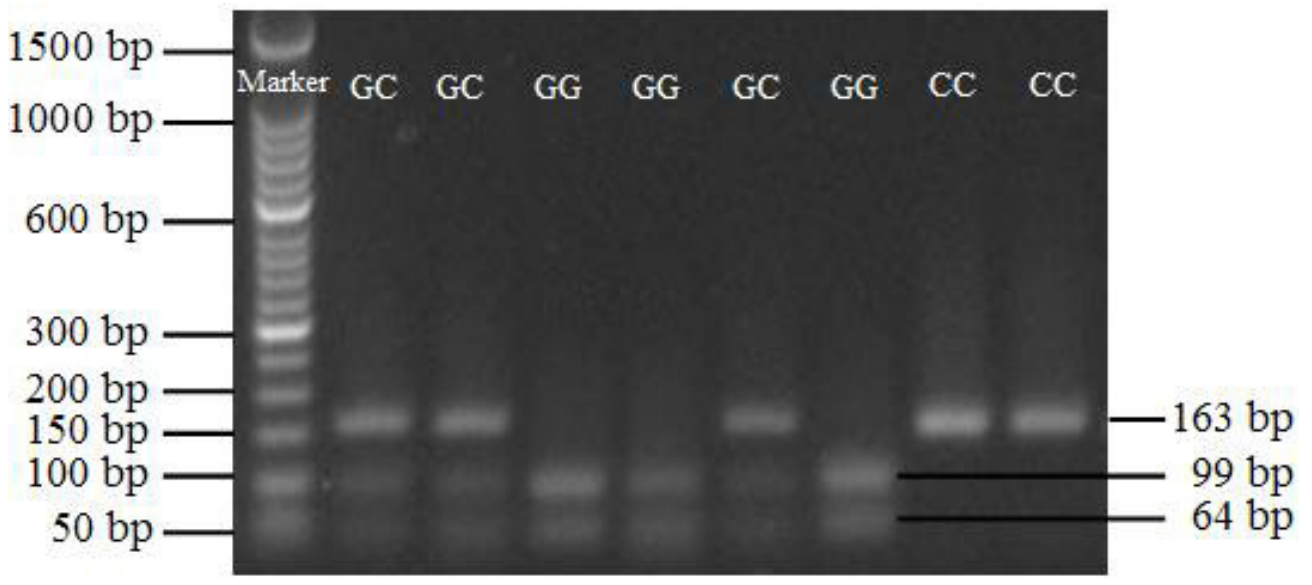

Figure 4. RFLP electrophoresis patterns of bovine $S M O$ gene exon 9 (21,234-bp locus). 


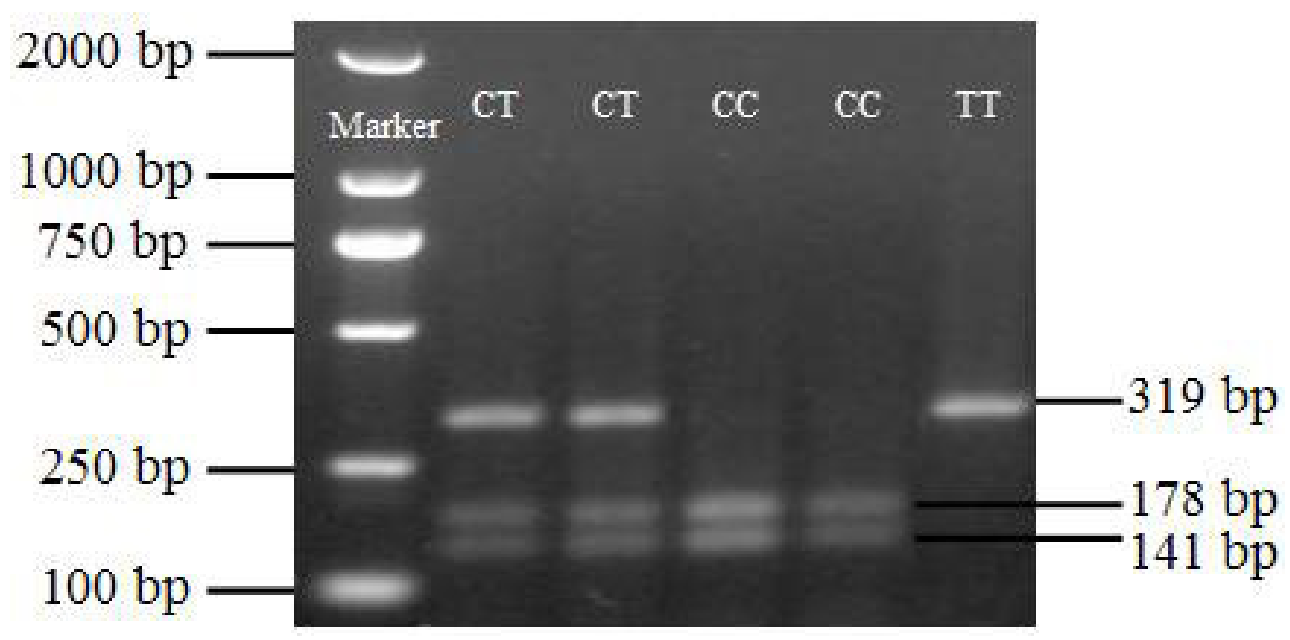

Figure 5. RFLP electrophoresis patterns of bovine $S M O$ gene exon 11 (22,424-bp locus).

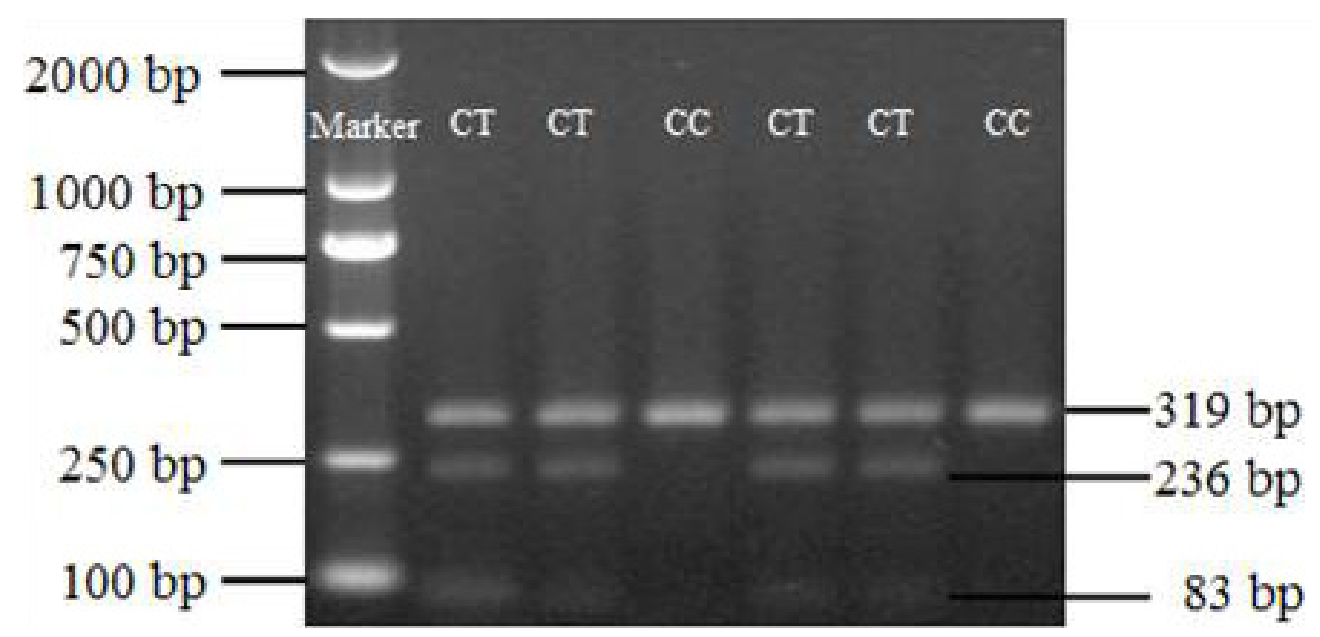

Figure 6. RFLP electrophoresis patterns of bovine $S M O$ gene exon 11 (22,481-bp locus). Fragment of 83 bp was not clear.

The genotype and allele frequencies of the 3 loci were calculated, the chi-square test (Tables 1-3) was performed for the 562 individuals. The results showed that the genotype distribution of G21234C SNP was not in Hardy-Weinberg equilibrium $\left(\chi^{2}>\chi_{0.05}{ }^{2}\right)$, whereas both C22424T and C22481T SNPs were in Hardy-Weinberg equilibrium $\left(\chi^{2}<\chi_{0.05}{ }^{2}\right)$. For the G21234C SNP, GC had the highest genotype frequency, followed by GG and CC. For the C22424T SNP, CC had the highest genotype frequency, followed by CT and TT. For the C22481T SNP, CC had a higher genotype frequency compared to CT. 
Table 1. Genotype frequencies of G21234C SNP of the SMO gene in Qinchuan cattle population.

\begin{tabular}{|c|c|c|c|c|c|c|c|}
\hline & \multicolumn{3}{|c|}{ Genotypic frequencies } & \multirow[t]{2}{*}{ Total } & \multicolumn{2}{|c|}{ Allelic frequencies } & \multirow[t]{2}{*}{$\chi^{2}(\mathrm{HW})$} \\
\hline & GG & GC & $\mathrm{CC}$ & & $\mathrm{G}$ & $\mathrm{C}$ & \\
\hline Population & $0.3577(201)$ & $0.5427(305)$ & $0.0996(56)$ & 562 & 0.6290 & 0.3710 & 14.8979 \\
\hline
\end{tabular}

$\mathrm{HW}=$ Hardy-Weinberg equilibrium; $\chi_{0.05}{ }^{2}=5.991, \chi_{0.01}{ }^{2}=9.21$.

Table 2. Genotype frequencies of C22424T SNP of the SMO gene in Qinchuan cattle population.

\begin{tabular}{|c|c|c|c|c|c|c|c|}
\hline & \multicolumn{3}{|c|}{ Genotypic frequencies } & \multirow[t]{2}{*}{ Total } & \multicolumn{2}{|c|}{ Allelic frequencies } & \multirow[t]{2}{*}{$\chi^{2}(\mathrm{HW})$} \\
\hline & $\mathrm{CC}$ & $\mathrm{CT}$ & $\mathrm{TT}$ & & $\mathrm{C}$ & $\mathrm{T}$ & \\
\hline Population & $0.6584(370)$ & $0.3185(179)$ & $0.0231(13)$ & 562 & 0.8176 & 0.1824 & 2.5947 \\
\hline
\end{tabular}

HW $=$ Hardy-Weinberg equilibrium; $\chi_{0.05}{ }^{2}=5.991, \chi_{0.01}{ }^{2}=9.21$.

Table 3. Genotype frequencies of C22481T of the SMO gene in Qinchuan cattle population.

\begin{tabular}{|c|c|c|c|c|c|c|}
\hline & \multicolumn{2}{|c|}{ Genotypic frequencies } & \multirow[t]{2}{*}{ Total } & \multicolumn{2}{|c|}{ Allelic frequencies } & \multirow[t]{2}{*}{$\chi^{2}(\mathrm{HW})$} \\
\hline & $\mathrm{CC}$ & CT & & $\mathrm{C}$ & $\mathrm{T}$ & \\
\hline Population & $0.8238(463)$ & $0.1762(99)$ & 562 & 0.9119 & 0.0881 & 5.2427 \\
\hline
\end{tabular}

HW $=$ Hardy-Weinberg equilibrium; $\chi_{0.05}^{2}=5.991, \chi_{0.01}{ }^{2}=9.21$.

Based on the allele frequencies of the 3 mutant loci, $H_{\mathrm{E}}, H_{\mathrm{O}}, N_{\mathrm{E}}$, and PIC were analyzed (Table 4). The $H_{\mathrm{E}}, N_{\mathrm{E}}$, and PIC values of G21234C, C22424T, and C22481T SNPs were $0.4667,1.8752$, and $0.3578,0.2982,1.4250$ and 0.2538 , and $0.1606,1.1941$, and 0.1477 , respectively. According to a standard (high, medium, and low polymorphism if PIC $>0.5,0.25$ $<$ PIC $<0.5$, or PIC $<0.25$, respectively; Ma et al., 2011), both G21234C and C22424T loci had a medium level of polymorphism, while C22481T locus had a low level of polymorphism.

Table 4. Genetic indexes of G21234C, C22424T, and C22481T loci of the SMO gene in Qinchuan cattle population.

\begin{tabular}{lcccc}
\hline Locus & Gene homozygosity $\left(H_{\mathrm{O}}\right)$ & Gene heterozygosity $\left(H_{\mathrm{E}}\right)$ & Effective allele numbers $\left(N_{\mathrm{E}}\right)$ & Polymorphic Information Content $($ PIC) \\
\hline $\mathrm{G} 21234 \mathrm{C}$ & 0.5333 & 0.4667 & 1.8752 & 0.3578 \\
$\mathrm{C} 22424 \mathrm{~T}$ & 0.7018 & 0.2982 & 1.4250 & 0.2538 \\
$\mathrm{C} 22481 \mathrm{~T}$ & 0.8394 & 0.1606 & 1.1914 & 0.1477 \\
\hline
\end{tabular}

\section{Effect of the polymorphisms on the BMTs and MQTs in the SMO gene}

\section{G21234C SNP}

Significant differences were obtained among the different G21234C SNP genotypes for BL, WH, RL, HW, CD, HG, and UBT. The mean value of individuals with the GG genotype was significantly higher compared to those with the CC genotype for BL, WH, RL, CD, 
and HG $(\mathrm{P}<0.05)$, and was very significantly higher for HW and UBT $(\mathrm{P}<0.01)$ (Table 5). The mean value of individuals with the GG genotype was significantly higher compared to those with the GC genotype for UBT $(\mathrm{P}<0.01)$, and significantly higher for $\mathrm{WH}(\mathrm{P}<0.05)$. No significant difference was detected between the genotypes and all other traits $(\mathrm{P}>0.05)$.

\begin{tabular}{|c|c|c|c|}
\hline \multirow[t]{2}{*}{ Traits (means $\pm \mathrm{SE}$ ) } & \multicolumn{3}{|c|}{ Genotypes } \\
\hline & GG & GC & $\mathrm{CC}$ \\
\hline BL (cm) & $133.065^{\mathrm{a}} \pm 0.940$ & $131.766^{\mathrm{ab}} \pm 0.830$ & $128.773^{b} \pm 1.434$ \\
\hline WH $(\mathrm{cm})$ & $120.876^{\mathrm{a}} \pm 0.625$ & $119.047^{b} \pm 0.545$ & $118.193^{b} \pm 1.087$ \\
\hline $\mathrm{HH}(\mathrm{cm})$ & $123.575 \pm 0.552$ & $122.184 \pm 0.479$ & $121.432 \pm 0.928$ \\
\hline RL (cm) & $41.706^{\mathrm{a}} \pm 0.327$ & $41.389^{\mathrm{a}, \mathrm{b}} \pm 0.294$ & $40.046^{\mathrm{b}} \pm 0.554$ \\
\hline $\mathrm{HW}(\mathrm{cm})$ & $38.549^{\mathrm{A}} \pm 0.443$ & $37.606^{\mathrm{A}, \mathrm{B}} \pm 0.371$ & $36.091^{\mathrm{B}} \pm 0.753$ \\
\hline $\mathrm{CD}(\mathrm{cm})$ & $58.794^{\mathrm{a}} \pm 0.550$ & $57.878^{\mathrm{a}, \mathrm{b}} \pm 0.451$ & $55.943^{b} \pm 0.924$ \\
\hline $\mathrm{HG}(\mathrm{cm})$ & $162.628^{\mathrm{a}} \pm 1.341$ & $160.108^{\mathrm{a}, \mathrm{b}} \pm 1.159$ & $155.750^{b} \pm 1.821$ \\
\hline PBW (cm) & $18.536 \pm 0.237$ & $18.137 \pm 0.219$ & $17.864 \pm 0.395$ \\
\hline UBT $(\mathrm{cm})$ & $0.907^{\mathrm{A}} \pm 0.025$ & $0.829^{\mathrm{B}} \pm 0.018$ & $0.775^{\mathrm{B}} \pm 0.027$ \\
\hline $\operatorname{ULA}\left(\mathrm{cm}^{2}\right)$ & $44.870 \pm 1.109$ & $45.025 \pm 0.904$ & $40.925 \pm 1.395$ \\
\hline
\end{tabular}

a,b Means with different superscripts are significantly different $(\mathrm{P}<0.05) .{ }^{\mathrm{A}, \mathrm{B}}$ Means with different superscripts are significantly different $(\mathrm{P}<0.01)$.

\section{C22424T SNP}

Significant differences were obtained among the 3 C22424T SNP genotypes for BL, $\mathrm{HW}, \mathrm{CD}, \mathrm{HG}$, and UBT. The mean value of animals with the CT genotype was significantly higher compared to those with the with the $\mathrm{CC}$ genotype for $\mathrm{BL}(\mathrm{P}<0.01)$, and also significantly higher for HW, CD, HG, and UBT $(\mathrm{P}<0.05)$. No significant difference was detected between the genotypes and all other traits $(\mathrm{P}>0.05)$ (Table 6).

\begin{tabular}{|c|c|c|c|}
\hline \multirow[t]{2}{*}{ Traits (means \pm SE) } & \multicolumn{3}{|c|}{ Genotypes } \\
\hline & $\mathrm{CC}$ & CT & TT \\
\hline $\mathrm{BL}(\mathrm{cm})$ & $130.504^{\mathrm{B}} \pm 0.675$ & $134.878^{\mathrm{A}} \pm 1.106$ & $131.667^{\mathrm{AB}} \pm 3.488$ \\
\hline WH $(\mathrm{cm})$ & $119.181 \pm 0.471$ & $120.537 \pm 0.708$ & $119.444 \pm 2.346$ \\
\hline $\mathrm{HH}(\mathrm{cm})$ & $122.290 \pm 0.416$ & $123.274 \pm 0.609$ & $122.500 \pm 2.288$ \\
\hline $\mathrm{RL}(\mathrm{cm})$ & $41.204 \pm 0.259$ & $41.696 \pm 0.351$ & $41.333 \pm 1.236$ \\
\hline $\mathrm{HW}(\mathrm{cm})$ & $37.394^{b} \pm 0.326$ & $38.556^{\mathrm{a}} \pm 0.479$ & $38.556^{\mathrm{ab}} \pm 2.205$ \\
\hline $\mathrm{CD}(\mathrm{cm})$ & $57.396^{\mathrm{b}} \pm 0.367$ & $59.185^{\mathrm{a}} \pm 0.650$ & $59.333^{\mathrm{ab}} \pm 3.501$ \\
\hline $\mathrm{HG}(\mathrm{cm})$ & $159.256^{\mathrm{b}} \pm 0.950$ & $163.126^{\mathrm{a}} \pm 1.559$ & $162.778^{\mathrm{ab}} \pm 6.087$ \\
\hline PBW (cm) & $18.072 \pm 0.180$ & $18.622 \pm 0.286$ & $18.333 \pm 0.707$ \\
\hline UBT $(\mathrm{cm})$ & $0.827^{b} \pm 0.015$ & $0.902^{\mathrm{a}} \pm 0.028$ & $0.872^{\mathrm{ab}} \pm 0.102$ \\
\hline $\operatorname{ULA}\left(\mathrm{cm}^{2}\right)$ & $43.881 \pm 0.778$ & $45.873 \pm 1.215$ & $45.073 \pm 2.656$ \\
\hline
\end{tabular}

\section{C22481T SNP}

No significant difference $(\mathrm{P}>0.05)$ was obtained between the 2 genotypes detected from C22481T SNP and any of the 10 traits evaluated in this study (data not shown). 


\section{DISCUSSION}

A large number of previous studies have elucidated that the important economic traits of livestock (i.e., quantitative traits, such as growth rate, meat quality, and meat quantity) are affected by both multiple genetic loci and non-genetic factors. Molecular genetic information and the identification of the quantitative trait locus (QTL) associated with important economic characteristics are expected to contribute to the genetic improvement of animals, and promote Chinese indigenous cattle breeding programs (Adoligbe et al., 2012). Candidate gene approach is used as a common and crucial tool to investigate the association between gene polymorphisms and important economic traits in livestock. This approach begins with the first and important step of selecting a putative candidate gene, according to its relevance in the mechanism of the traits being studied (Kwon and Goate, 2000). Previous studies of Drosophila melanogaster and mice provide evidence that SMO, which is a signal transducer, plays an important role in the regulation of both adipogenesis and osteogenesis through the Hedgehog (Hh) pathway (Long et al., 2001; Suh et al., 2006). Thus, the SMO gene could serve as an attractive candidate gene for both BMTs and MQTs in Qinchuan Cattle genetic improvement programs.

In this study, 3 novel SNPs of the bovine SMO gene were detected in 562 Qinchuan cattle. The G21234C and C22424T SNPs exhibited 3 genotypes, while the C22481T SNP exhibited 2 genotypes. The genotype distribution of G21234C SNP was not in Hardy-Weinberg equilibrium $\left(\chi^{2}>\chi_{0.05}{ }^{2}\right)$, whereas both C22424T and C22481T SNPs were $\left(\chi^{2}<\chi_{0.05}{ }^{2}\right)$. Gene random drift or the relatively small experimental sample size might explain the absence of the TT genotype in the C22481T SNP and for the G21234C SNP genotype distribution not being in Hardy-Weinberg equilibrium.

Association analysis showed that the G21234C SNP affected the BL, WH, RL, HW, $\mathrm{CD}, \mathrm{HG}$, and UBT $(\mathrm{P}<0.05$ or $\mathrm{P}<0.01)$. In addition, the C22424T SNP affected the BL, HW, $\mathrm{CD}, \mathrm{HG}$, and UBT $(\mathrm{P}<0.05$ or $\mathrm{P}<0.01)$. Both the GG genotype of the G21234C SNP and the CT genotype of the C22424T SNP are, therefore, considered favorable for selecting cattle with superior BMTs and MQTs. The G21234C and C22424T SNPs of the bovine SMO gene resulted in the synonymous mutation of arginine and glycine in the SMO protein, respectively. This process does not alter the amino acid sequence of the gene product; however, because of the codon bias, this process might influence the rate of translation from mRNA to the SMO protein, thus affecting protein structure and function (Liu et al., 2005; Kimchi-Sarfaty et al., 2007) and influencing the transmission of Hh signals. When the C22481T SNP contributed to a histidine synonymous mutation, the $\mathrm{CC}$ and $\mathrm{CT}$ genotypes were detected, with no significant difference being found between these 2 genotypes with all of the traits assessed in this study. This result might be caused by the equivalent effect of the $\mathrm{CC}$ and $\mathrm{CT}$ genotypes on translation from mRNA to the SMO protein, and also protein structure. Furthermore, the TT genotype was not detected for C22481T SNP in this study; hence, it remains unclear whether C22481T SNP influences any BMTs and MQTs.

Molecular marker-assisted selection (MAS) based on genetic variation is regarded as a potential method for genetically improving livestock bred for better economic traits. Using the candidate gene approach, previous studies have investigated the association of important economic traits, such as growth (Gao et al., 2011), reproduction (An et al., 2012), and meat quality traits (Fu et al., 2013), to identify useful genetic markers. This study provides the first report of 3 novel SNPs of the bovine SMO gene, which are expected to extend the spectrum 
of genetic variation of the bovine SMO gene, and contribute to our knowledge about bovine genetic resources for breeding programs. The results of this study indicate that the $S M O$ gene could be used as a candidate gene influencing the BMTs and MQTs of Chinese native indigenous cattle. Furthermore, both the G21234C SNP and C22424T SNP of the bovine SMO gene could be used as molecular markers for selecting cattle with superior BMTs and MQTs. However, further studies using larger populations are required, with the goal of using the associated SNPs for marker-assisted selection (MAS) and to validate the observed associations.

\section{ACKNOWLEDGMENTS}

We thank all of the research assistants and laboratory technicians who contributed to this study. We extend special thanks to Professor Zan and Dr. Wang for their assistance. Research supported by the National Natural Science Foundation of China (\#31272411), the National "863" Program of China (\#2011AA100307-02, \#2013AA102505), and the National Science-Technology Support Program of China (\#2011BAD28B04-03).

\section{REFERENCES}

Adoligbe C, Zan L, Farougou S, Wang H, et al. (2012). Bovine GDF10 gene polymorphism analysis and its association with body measurement traits in Chinese indigenous cattle. Mol. Biol. Rep. 39: 4067-4075.

Alcedo J, Ayzenzon M, Von Ohlen T, Noll M, et al. (1996). The Drosophila smoothened gene encodes a seven-pass membrane protein, a putative receptor for the hedgehog signal. Cell 86: 221-232.

An XP, Hou JX, Li G, Song YX, et al. (2012). Polymorphism identification in the goat KITLG gene and association analysis with litter size. Anim. Genet. 43: 104-107.

Ayers KL and Therond PP (2010). Evaluating Smoothened as a G-protein-coupled receptor for Hedgehog signalling. Trends Cell Biol. 20: 287-298.

Brethour JR (1994). Estimating marbling score in live cattle from ultrasound images using pattern recognition and neural network procedures. J. Anim. Sci. 72: 1425-1432.

Evangelista M, Tian H and de Sauvage FJ (2006). The hedgehog signaling pathway in cancer. Clin. Cancer Res. 12: 5924-5928.

Fu CZ, Wang H, Mei CG, Wang JL, et al. (2013). SNPs at 3'-UTR of the bovine CDIPT gene associated with Qinchuan cattle meat quality traits. Genet. Mol. Res. 12: 775-782.

Gao L, Zan LS, Wang HB, Hao RJ, et al. (2011). Polymorphism of somatostatin gene and its association with growth traits in Chinese cattle. Genet. Mol. Res. 10: 703-711.

Gering M and Patient R (2005). Hedgehog signaling is required for adult blood stem cell formation in zebrafish embryos. Dev. Cell 8: 389-400.

Gilbert RP, Bailey DR and Shannon NH (1993). Linear body measurements of cattle before and after 20 years of selection for postweaning gain when fed two different diets. J. Anim. Sci. 71: 1712-1720.

Hamlin KE, Green RD, Cundiff LV, Wheeler TL, et al. (1995). Real-time ultrasonic measurement of fat thickness and longissimus muscle area: II. Relationship between real-time ultrasound measures and carcass retail yield. J. Anim. Sci. 73: 1725-1734.

Ingham PW and McMahon AP (2001). Hedgehog signaling in animal development: paradigms and principles. Genes Dev. 15: 3059-3087.

Jia J and Jiang J (2006). Decoding the Hedgehog signal in animal development. Cell Mol. Life Sci. 63: 1249-1265.

Kimchi-Sarfaty C, Oh JM, Kim IW, Sauna ZE, et al. (2007). A "silent" polymorphism in the MDR1 gene changes substrate specificity. Science 315: 525-528.

Kwon JM and Goate AM (2000). The candidate gene approach. Alcohol Res. Health 24: 164-168.

Li X, Blagden CS, Bildsoe H, Bonnin MA, et al. (2004). Hedgehog can drive terminal differentiation of amniote slow skeletal muscle. BMC Dev. Biol. 4: 9.

Liu Q, Dou S, Ji Z and Xue Q (2005). Synonymous codon usage and gene function are strongly related in Oryza sativa. Biosystems 80: 123-131. 
Long F, Zhang XM, Karp S, Yang Y, et al. (2001). Genetic manipulation of hedgehog signaling in the endochondral skeleton reveals a direct role in the regulation of chondrocyte proliferation. Development 128: 5099-5108.

Ma L, Qu YJ, Huai YT, Li ZJ, et al. (2011). Polymorphisms identification and associations of KLF7 gene with cattle growth traits. Livest. Sci. 135: 1-7.

McMahon AP, Ingham PW and Tabin CJ (2003). Developmental roles and clinical significance of hedgehog signaling. Curr. Top. Dev. Biol. 53: 1-114.

Mullenbach R, Lagoda PJ and Welter C (1989). An efficient salt-chloroform extraction of DNA from blood and tissues. Trends Genet. 5: 391.

Nei M and Roychoudhury AK (1974). Sampling variances of heterozygosity and genetic distance. Genetics 76: 379-390.

Nei M and Li WH (1979). Mathematical model for studying genetic variation in terms of restriction endonucleases. Proc. Natl. Acad. Sci. U. S. A. 76: 5269-5273.

Suh JM, Gao X, McKay J, McKay R, et al. (2006). Hedgehog signaling plays a conserved role in inhibiting fat formation. Cell Metab. 3: 25-34.

Varjosalo M and Taipale J (2008). Hedgehog: functions and mechanisms. Genes Dev. 22: 2454-2472.

Wu X, Walker J, Zhang J, Ding S, et al. (2004). Purmorphamine induces osteogenesis by activation of the hedgehog signaling pathway. Chem. Biol. 11: 1229-1238. 